\title{
Reforma psiquiátrica: política, paradigma epistemológico, assistência e cultura
}

\author{
Psychiatric reform: politics, epistemological \\ paradigm, assistance and culture
}

\author{
Maurício Viotti Daker \\ Professor associado do Departamento de Saúde Mental/ \\ Faculdade de Medicina/Universidade Federal de Minas Gerais. \\ daker@ufmg.br
}

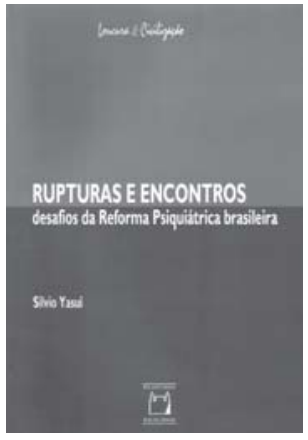

YASUI, Silvio. Rupturas e encontros: desafios da reforma psiquiátrica brasileira. Rio de Janeiro: Editora Fiocruz, 2010. (Coleção Loucura e Civilização). 192p.
$S$ ilvio Yasui nos brinda com quase duzentas páginas de profunda vivência no processo da denominada 'reforma psiquiátrica', alicerçado em considerável base conceitual. Transmite-nos ideia clara do que se entende por esse complexo processo. Apoia-se em quatro dimensões interligadas da reforma, em sintonia com seu orientador nessa tese, Paulo Amarante. São elas: jurídico-política (com ênfase na política), epistemológica ou teórico-conceitual, técnico-assistencial e sociocultural, correspondente à subdivisão do livro nos seguintes capítulos: "Movimento social e política pública", "A reforma psiquiátrica e a transição paradigmática", "Caps: estratégia de produção de cuidados" e "Plantadores de sonhos: a reforma psiquiátrica é um processo civilizador". O prefácio é de Ana Pitta.

No primeiro capítulo, lembra-nos que no ato fundador da psiquiatria já se encontravam em cena os termos reforma, política e Estado, no contexto da Revolução Francesa, sob a batuta de Pinel.

Relata alguns passos iniciais da psiquiatria brasileira nos séculos XIX e XX. Salvo por experiências muito pontuais, levanta de pronto o alerta: essas reformas, ainda quando atreladas a contextos políticos, econômicos, sociais e culturais, diferem-se da atual proposta da reforma psiquiátrica. No início dos anos 1970, chegaram a surgir diretrizes para a assistência psiquiátrica, em nível pan-americano e nacional, algumas delas semelhantes às que viriam a ser assumidas pela reforma psiquiátrica, como criar centros comunitários de saúde mental, estimulando-se a participação da comunidade em torno deles, modernizar a legislação pertinente, priorizar o atendimento ambulatorial e hospitalização breve, de preferência em hospitais gerais etc. Porém, não passaram de letras mortas diante de interesses contrários, como, por exemplo, o bom negócio gerado pela privatização de leitos financiados pelo erário. Foi necessário o contexto histórico e político de renascimento dos movimentos sociais e da redemocratização do país, surgido na segunda metade da década de 1970, para que as atuais reformas, tanto sanitária quanto psiquiátrica, encontrassem terreno fértil. Entra em cena, vigorosamente, a ideia de que transformar a saúde é transformar a sociedade, para além dos serviços: eis a principal diferença dessa para as demais 
reformas. A reforma sanitária se coloca fundamentalmente como processo político, "que levava à produção intelectual crítica, práticas e ações alternativas ao modelo hegemônico, militância cotidiana, ocupação de espaços institucionais, articulações com outros setores da sociedade, ocupação de espaços no interior do aparato estatal" (p.30, 31). A reforma psiquiátrica, incentivada por atores externos como Basaglia, procurou igualmente politizar a questão da saúde mental, "especialmente na luta contra instituições psiquiátricas; produziu reflexões críticas que provocaram uma ruptura epistemológica; criou experiências e estratégias de cuidado contra-hegemônicas; conquistou mudanças em normas legais e buscou produzir efeitos no campo sociocultural" (p.31). Foram muitos e efervescentes os eventos e organizações em que essas questões se colocavam (no congresso de 1978 da 'conservadora' Associação Brasileira de Psiquiatria), de maneira ampla, aliás, com grande repercussão na sociedade. Em nível administrativo estatal houve a criação de entidades que possibilitaram avançar em direção ao Sistema Único de Saúde e aos princípios da reforma sanitária na Constituição Federal de 1988. Surgiu, em 1987, o movimento da luta antimanicomial. Vieram os primeiros centros de atenção psicossociais (Caps) ou núcleos de atenção psicossociais (Naps). Em 1989, foi aprovada na Câmara dos Deputados projeto de lei em prol da reforma psiquiátrica (lei assinada no Senado apenas em 2001 e modificada em sua essência), defendendo a extinção progressiva dos hospitais psiquiátricos e sua substituição por outros recursos assistenciais, o que estimulou promulgação de leis estaduais nesse sentido. Portarias ministeriais em prol dos Caps os incentivaram financeiramente e os tornaram centrais na assistência à saúde mental. Em que pesem todos esses avanços, o autor mantém-se alerta quanto ao real aspecto fundamental transformador social revolucionário. Chega a falar de "minimanicômios de portas abertas e mentes fechadas" (p.70), que exclui e segrega sem muros, referindose a muitos dos Caps hoje existentes, criados às vezes por simples interesse financeiro dos municípios e compostos por pessoas não preparadas para essa grande tarefa transformadora. E acrescenta: "Se nossa prática gera saberes, não há como negar, também, que gera poderes no microcosmos desses novos serviços, os quais hoje se transformaram em uma ação de Estado. Qual o efeito que tal poder estará produzindo? Efetivará uma ruptura que promova a emergência ou a constituição de novas subjetividades mais autônomas, mais livres? Ou, cooptado e esvaziado de sua potencialidade transformadora, será reduzido a mais um dispositivo de controle e de dominação?" (p.72).

Em "A reforma psiquiátrica e a transição paradigmática", ressalta a produção de novos conceitos para novos problemas e objetos. A racionalidade científica moderna é questionada. Através dela, os fenômenos da ordem humana se teriam submetido ao domínio e controle que se exercem sobre a natureza, como objetos manipuláveis, procedimento reificante e matematizante, negando-se sua dimensão histór'ico-cultural e humana. As qualidades do objeto são menos importantes do que suas características quantificáveis. E "não mais reflexão sobre valores, porém, sim, sobre eficiência e eficácia" (p.80). O modelo explicativomecanicista, o método experimentalista-indutivista e a linguagem matematizante impregnaram a racionalidade científica médica e psiquiátrica. Da eliminação da doença do corpo dos indivíduos nasce a saúde na medicina moderna (saúde como ausência de patologia e não como afirmação da vida), e a loucura tornou-se objeto médico, ganhando valor de doença. O princípio reducionista/simplificador da racionalidade científica quer nos explicar 
os transtornos mentais em termos neuropatológicos, neuroquímicos ou neurocientíficos, sem espaço para outras formas de conhecimento sobre o psiquismo. Não obstante, esse paradigma científico da modernidade vem-se mostrando em crise há algum tempo, a partir de investigações na própria física e em outras áreas básicas: “Tempo e espaço como não absolutos, interferência do observador no fenômeno, relativização do rigor matemático e auto-organização criativa dos sistemas. $\mathrm{O}$ antigo/moderno mundo estático e sujeito às leis imutáveis e deterministas vai sendo substituído pela visão de um universo instável e dinâmico, reino da incerteza, do acaso e da criatividade" (p.93). Freud introduziu seu conceito de inconsciente e falou da incompletude do humano com sua falta inaugural e estruturante, ao contrário daquele homem racional poderoso e autônomo frente à natureza. Como bem coloca o autor, é esse sujeito desejante, carecendo do Outro para produzir e reproduzir permanentemente sua subjetividade, que também produz ciência. Torna-se plausível considerar como ideologia o conceito de ciência e tecnologia. Advém, então, transição epistemológica paradigmática e que dá sustentação à reforma psiquiátrica. São mencionados, nesse sentido, autores como Gaston Bachelard, Edgar Morin, Ilya Prigogine e Isabelle Stengers, Pierre-Félix Guattari, Boaventura Souza Santos. Fala-se da noção de complexidade, que permite incorporar a desordem, a contradição, a incerteza, o acaso (resíduos descartáveis considerados não científicos) na problemática geral do conhecimento científico. Fala-se da nova aliança entre homem e natureza e entre ciência e filosofia, rompendo-se com a dicotomia sujeito/objeto. No tocante à reforma psiquiátrica: "Ao romper com a visão biológica reducionista e produzir uma desmontagem dos conceitos basilares da psiquiatria, ela propõe construir/tecer/inventar o seu campo teórico-conceitual, estabelecendo um amplo, profundo e radical diálogo entre as diferentes disciplinas e conhecimentos que tratam do humano" (p.101). Envolvida nesse trabalho está a coletividade, uma ampla rede de cuidados (familiares, amigos, colegas da escola, do trabalho) e não simplesmente equipes multiprofissionais que apenas se constituam de profissionais compartilhando um mesmo espaço. Esse trabalho "só pode ser concretizado como uma prática social que sonha utopias, que trabalha e acredita em uma sociedade mais justa e igualitária, que respeite radicalmente as diferenças" (p.112). O autor sintetiza em um quadro as principais características do modelo psiquiátrico e do novo modelo assistencial/atenção psicossocial.

Em "Caps: estratégia de cuidados" é mencionado o conceito de práxis baseado em Marx, que seria o fundamento do conhecimento, de onde nascem conceitos que se transmutam em instrumentos teóricos e técnicos. O Caps deve ser entendido como 'estratégia', que significa, referindo-se o autor ao dicionário Houaiss, "a arte de aplicar com eficácia os recursos de que se dispõe ou de explorar as condições favoráveis de que porventura se desfrute, visando ao alcance de determinados objetivos" (p.115). O Caps é meio e não fim, ele compõe ampla rede de alianças possíveis em seu território, assumindo a responsabilidade sobre sua demanda. Os termos território, responsabilização, acolhimento, cuidado e rede são fundamentais e bem delineados nesse capítulo. Cuidar significa "romper com uma racionalidade médica que instrumentaliza saberes e práticas hegemônicas centradas na doença, de caráter hospitalocêntrico, excessivamente farmacológico e de orientação biologizante. Ruptura que inaugura uma relação diferente entre o sujeito que sofre e o cuidador que toma o existir humano em sua complexidade. As estratégias de intervenção daí decorrentes 
ampliam-se para a construção de projetos marcados pela diversidade. Cuidar é montar, tecer projetos de vida. É uma relação" (p.120). Baseando-se em Espinoza, o ato de cuidar será sempre uma busca de propiciar bons encontros, originados de afetos alegres e que produzem vida. Sem que levem, porém, à dependência ou tutela. Quanto ao território, observa-se a inseparabilidade estrutural, funcional e processual entre a sociedade e o espaço geográfico. Procura-se criar um novo lugar social para a loucura, para além do serviço. E mais, sem que a loucura seja 'domesticada' ou 'domada', mantendo sua potencialidade de disrupção, permitir que "essa radical diferença da desrazão possa habitar em toda a sua plenitude provocativa" (p.130). O conceito de território atrela-se ao de processo, de relação, não é apenas um frio mapa: "haverá para cada Caps um território com sua singularidade, e, em cada Caps, tantos territórios quantos os usuários que lá se encontrarão” (p.130). São enfatizados o projeto terapêutico individual (PTI) e a diversidade de estratégias de cuidados. Alerta-se sobre potenciais críticas ao funcionamento das equipes de saúde mental. Devem ser criativas, abrir novos caminhos, construir alianças na sociedade, enfim, estar aptas e dispostas a fazer história.

"Plantadores de sonhos: a reforma psiquiátrica é um processo civilizador" reitera a reforma como "processo social complexo" (p.161), referindo-se a Amarante, algo em permanente movimento e sem um fim predeterminado. Remete-nos, especialmente, a uma radical ruptura paradigmática epistemológica, ao encontro de possibilidades e não de certezas definitivas: "No lugar de uma ciência autônoma e independente e de cientistas acima do bem e do mal, encontra a história do homem e a defesa de seus interesses, produzindo saber para legitimar poder" (p.162). A ênfase é na "produção de relações sociais pautadas por princípios e valores que buscam reinventar a sociedade, constituindo um novo lugar para o louco" (p.172). O manicômio representa a expressão dos mecanismos de opressão de nossa sociedade. O autor aponta nesse capítulo dois aspectos da dimensão sociocultural: ações culturais e artísticas, e a utopia de mudar o mundo, a reforma como processo civilizador. Utopia como necessidade fundamental do ser humano, sonhos, não apenas relações regidas pela lógica globalizante e massificadora do mercado. Realçam-se valores de justiça social, liberdade e igualdade. Trata-se, enfim, de processo social complexo a engendrar processo civilizador que envolve toda a sociedade e grupos menos favorecidos, não apenas o louco.

A síntese acima serve apenas de breve introdução ao rico aporte do livro. É certo que o tema acarreta boas, necessárias e esperadas discussões, que não cabe aprofundar nesta resenha. Enquanto psiquiatra, apenas gostaria de transmitir que a psiquiatria, campo por si sabidamente complexo, possui vários fronts conceituais e de ação, sendo muitos deles simpáticos às propostas da reforma psiquiátrica, outros certamente antagônicos. Diria que haveria mais concordâncias, em termos de 70-80\%. Que seja a reforma a busca de uma utopia, como relata o próprio autor, mas essa busca traz resultados reais. O ser humano costuma proceder assim. No entanto, como é de esperar de nossa parte, psiquiatras, os remanescentes pontos de discórdia trazem, a nosso ver, prejuízos à assistência ao portador de transtornos mentais. Os amplos conhecimentos da psiquiatria - não apenas eventuais e estereotipadas orientações de momento, até oportunistas - nos parecem fundamentais para a reforma psiquiátrica ou, como preferimos, para a reforma da assistência psiquiátrica 
ou em saúde mental. Apenas a título de exemplo, muito se discutiu e se discute em psiquiatria sobre o conceito de doença mental, em vários sentidos. O próprio autor que estabeleceu as bases da classificação psiquiátrica, Kraepelin, questionou ao final de sua vida a existência de doenças no modelo tradicional. É sensato pensar, conforme os conhecimentos disponíveis, que os diversos fatores que possibilitam os transtornos mentais (não que os determinem), como os genes, encontram-se difusos ou diluídos na população geral. Isso indicaria que a loucura faz parte indissociável do ser humano, ou seja, que possivelmente não se trataria, simplesmente, de doença a ser erradicada. Antes ao contrário, até caberia a questão: existiria ser humano sem a loucura? Qual seria o papel, na mente humana, daquilo que se manifesta como estados psicopatológicos? Isso sem que se pretenda ou precise negar, por outro lado, que desvios ou desequilíbrios acentuados dos fatores predisponentes levam a estados mentais e comportamentais acompanhados de extremo sofrimento, que são realmente doentios. Tenhamos em mente, ainda, que esses fatores, além de seus aspectos individuais, singulares, frutos de uma história pessoal, valorizados devidamente pela reforma, também contêm algo de universal, seja psicossocial, seja biologicamente enraizado. Enfim, são questões que coloco no intuito de mostrar a possibilidade de se aprofundar a discussão ou o diálogo em torno de alguns pontos aparentemente antagônicos entre a reforma e a psiquiatria, em benefício da assistência.

Agora, permito-me expor interessante paradoxo. Acredito que boa parte do espírito da reforma psiquiátrica, sabidamente antipsiquiátrica, seja fundamental para a psiquiatria. Considero, aqui, aqueles essenciais segmentos ou fronts da psiquiatria que estão cientes de que ela só faz sentido, precisamente, na junção das ciências naturais com as humanas/ sociais, ou seria outra coisa, neurologia ou talvez neurociência clínica. Essa junção parece de grande interesse para todos, psiquiatras e reformistas da psiquiatria. 